\title{
Recent Development on Tobacco Control Policy in Indonesia: Analyzing Obstacles Faced by Indonesia in the Ratification of Framework Convention on Tobacco Control
}

\author{
Dodik Setiawan Nur Heriyanto \\ Faculty of Law, Islamic University of Indonesia \\ Jl. Tamansiswa No. 158 Yogyakarta \\ dodiksetiawan@uii.ac.id
}

\begin{abstract}
World Health Organization Framework Convention on Tobacco Control (the FCTC) was adopted on 21st May 2003 and came into force on $25^{\text {th }}$ February 2005. Since its adoption, Indonesia has never signed and ratified this Convention. Currently, Indonesia is the fifth largest tobacco market in the world and the third largest cigarrete consumer (WHO data in 2008), thus it is obligatory for Indonesia to obey the minimum standards of tobacco control under the FCTC. There are two problem formulations that will be answered by this writing: first, what are the obstacles faced by Indonesia during the ratification's plan of the FCTC? Second, how far the FCTC ratification is effective in protecting public health in Indonesia? This study is normative research by using statute and comparative approaches. Indonesian policy on tobacco control always face with obstacles in the area of politic, economic, and human rights side. Most of the laws are still abstract to support public health in general. Particular researches prove that ratification efforts done by Indonesia would not cause adverse impacts to the economic advantages of tobacco but yet would be able to give effective implementation and legal certainty to protect the public health.
\end{abstract}

Key words : Ratification, the FCTC, tobacco control policies, health right.

\begin{abstract}
Abstrak
Konvensi Kerangka Organisasi Kesehatan Dunia mengenai Pengendalian Tembakau (FCTC) diadopsi pada tanggal 21 Mei 2003 dan diberlakukan pada tanggal 25 Februari 2005. Sejak pencanangannya, Indonesia belum pernah menandatangani dan meratifikasi Konvensi ini. Saat ini Indonesia adalah pasar tembakau kelima terbesar di dunia dan konsumen rokok ketiga terbesar (data WHO tahun 2008), jadi hal ini merupakan kewajiban bagi Indonesia untuk mematuhi standar minimum pengendalian tembakau berdasarkan FCTC. Ada dua rumusan permasalahan yang akan dijawab dalam tulisan ini: pertama, hambatan-hambatan apa yang dihadapi oleh Indonesia pada saat perencanaan ratifikasi FCTC? Kedua, seberapa efektifkah ratifikasi FCTC dalam melindungi kesehatan masyarakat di Indonesia? Kajian ini merupakan penelitian normatif dengan menggunakan pendekatan statuta dan komparatif. Kebijakan pengendalian tembakau di Indonesia selalu menemui kendala dalam bidang politik, ekonomi, dan hak asasi manusia. Kebanyakan undang-undang masih bersifat abstrak dalam mendukung kesehatan masyarakat secara umum. Beberapa penelitian membuktikan bahwa upayaupaya ratifikasi yang dilakukan oleh Indonesia tidak akan berdampak buruk terhadap keuntungan ekonomi yang dihasilkan oleh tembakau, namun justru mampu memberikan implementasi yang efektif dan kepastian hukum untuk melindungi kesehatan masyarakat.
\end{abstract}

Kata kunci: Ratifikasi, FCTC, kebijakan pengendalian tembakau, bak kesebatan 


\section{Introduction}

The right to health becomes fundamental right to be given by every people in the world. This right is regulated in various international ${ }^{1}$ and national instruments. It means that in global perspective ${ }^{2}$, health right was becoming basic human rights, which should be protected by law and governmental policy.

In Indonesia, health right is also part of constitutional rights. Based on article $28 \mathrm{H}$ paragraph 1 of 1945 Constitution stated that every person shall have the right to live in physical and spiritual prosperity, to have a home and to enjoy a good and healthy environment, and shall have the right to obtain medical care. By this law, Indonesian government has an obligation to increase citizen's health standard.

Noting to the fact that smoking was becoming most of Indonesian's society behavior. From 1970 to 2006, tobacco consumption in Indonesia has increased to 33 bilion cigarretes. ${ }^{3}$ Smoking prevalencies among male has increased every year, such as $26,9 \%$ in $1995,31,5 \%$ in 2001 , and $38,4 \%$ in $2004 .{ }^{4}$ Another survey done by The Global Youth Survey (GYTS) also stated in the year 2006 approximately 37,3\% Indonesian students was reported smoking as a habit and around 30,9\% from them declared smoke in the first time at the age of ten years. ${ }^{5}$ In 2008 , based on WHO data, Indonesia ranked in the fifth largest tobacco market in the world ${ }^{6}$ and in the third largest cigarretes consument in the world ${ }^{7}$.

Recent facts about tobacco in Indonesia are very contrast with the government effort to increase people's health standard and care. This study first outlines the legal enforcement of tobacco control in Indonesia. Furthermore, this study also will describe general advantages of Framework Convention on Tobacco Control (the FCTC) ${ }^{8}$

\footnotetext{
${ }^{1}$ See UN Declaration of Human Rights (1948), International Covenant on Civil and Political Rights (1966), International Covenant for Economic Social and Cultural Rights (1966), and etc.

${ }^{2}$ Colleen M. Flood and Trudo Lemmens, "Global Health Challenges and The Role of Law", J.L. Med. \& Ethics, Vol. 41 (2013), p. 9.

${ }^{3}$ Badan Pusat Statistik (BPS/National Statistic Council), Survei Sosial Ekonomi Nasional (The National Socioeconomic Survey), Jakarta, 2006.

${ }^{4}$ Widyastuti Soerojo, “Epidemi Tembakau di Indonesia Tantangan Bagi Petugas Kesehatan”, paper on the Workshop Peningkatan Kapasitas Sektor Kesehatan Dalam Pengendalian Masalah Tembakau, Direktorat Pengendalian Penyakit Tidak Menular, Departemen Kesehatan Republik Indonesia, September 2007, p.5.

${ }^{5}$ Ibid. p.6.

${ }^{6}$ Indonesia Struggling to Deter Children from Smoking, available at http://english.peopledaily.com.cn/90001/90782/ 90880/7122690.html. Last visited 9 April 2014).

${ }^{7}$ Indonesia Masuk. Tiga Besar Konsumen Rokok, available at http:/ / www.arrahmah.com/read/2012/12/01/25181indonesia-masuk-tiga-besar-konsumen-rokok.html (last visited 9 April 2014).

${ }^{8}$ WHO Framework Convention on Tobacco Control, May 21, 2003-June 29, 2004, WHA56.1, 2302 U.N.T.S. 166, 42 I.L.M. 518 (hereinafter as 'the FCTC').
} 
ratification particularly for Indonesia. It will then analyse various obstacles of the FCTC ratification in Indonesia. Examples of ratification did by Indonesia will show how far the effective implementation of international obligations into Indonesian domestic law. Finally, this study will make legal conclusion to answer obstacles faced by Indonesia during the plan to bind with the FCTC.

\section{Statement of Problems}

There are two problem formulations that will be answered by this writing: first, what are the obstacles faced by Indonesia during the ratification's plan of the FCTC? Second, how far the FCTC ratification is effective in protecting public health in Indonesia?

\section{Research Purpose}

This research has two main purposes, such as: first, to deliberate the obstacles faced by Indonesia during the ratification's plan of the FCTC. Second, to analyze the effectivity of the FCTC ratification particularly to protect public health in Indonesia.

\section{Research Method}

This study is normative research by using statute and comparative approaches. The FCTC becomes the key regulation in this research. This research will deeply analyze its core substances and advantages. Moreover, this research also will analyze the existence of Indonesian regulation about tobacco control policy. By analyzing this domestic law, this research then will make comparative condition toward effective implementation of tobacco control policy under the FCTC rezim. Hopefully by this way of research, this study will present the comprehensive legal conclusion to answer the research questions.

Legal materials that support this research consist of primary, secondary, and tertiary research materials. The legal materials are to be collected and presented by descriptive and qualitative analysis. 


\section{Discussion and Result}

\section{Tobacco Control Policy in Indonesia}

To Implement article 28H paragraph 1 of 1945 Constitution on health right, Indonesia made several regulations especially focused on the tobacco control issue such as: Law No. 36 Year 2009 about Health, Government Regulation No. 109 Year 2012 about Securing Material Containing Addictive Substances, Minister of Health Regulation No. 28 Year 2013 about Imprinting of Health Warnings and Health Informations on Tobacco Product Packaging, and Joint Regulation between the Minister of Health No. 188/MENKES/PB/I/2011 and the Minister of Home Affairs No. 7 Year 2011 about Guideline Implementation of Non Smoking Area.

\section{Law No. 36 Year 2009 about Health}

Law No. 36 Year 2009 enacted as the implementation of article 28H paragraph (1) and article 34 paragraph (3) of 1945 Constitution. This Law actually less regulated about tobacco control. Not the whole of substance under this law regulated about tobacco control policy. It is regulated merely about the prohibition to produce and to import cigarretes in Indonesia without carrying health warnings (aritcle 114), list of non-smoking area and possibility of local government to stipulate non-smoking area (article 115), and cooperation between central and local government with society to communicate, inform, and educate about non communicable desease that come from smoking habits (article 160 section (2). This law also gives criminal sanction for every person who produce and import cigarretes without carrying picture of health warnings by maximum time of 5 years imprisonment and maximum fine 500.000 .000 IDR.

Substance about tobacco control in the Law No. 36 Year 2009 mostly was challenged by tobacco industry before the Constitutional Court. ${ }^{9}$ Moreover, during the process of this Law's enactment, there was an illegal attempt to remove certain article contain tobacco issue. ${ }^{10}$ Article 113 paragraph (2) of the Draft Law No. 36 Year

\footnotetext{
${ }^{9}$ There were five cases that challenged the existance of article about tobacco control and brought before the Constitutional Court. This Court stays in line with the spirit of tobacco control policy in accordance with the Constitution. See Muhammad Joni, Pasal Tembakau Terbanyak Uji Materiil: (Itu) Kontrol Bukan Diskriminasi, available at http:/ /www.advokatmuhammadjoni.com/opini/tulisan/170-pasal-tembakau-terbanyak-uji-materil-itu-kontrol-bukandiskriminasi.html. (last visited $21^{\text {st }}$ March 2014).

${ }^{10}$ See Ayat Tembakau Hilang di DPR, available at http:/ / nasional.kompas.com/read/2009/10/14/04594644/ ayat.tembakau.hilang.di.dpr (last visited $21^{\text {st }}$ March 2014).
} 
2009 intentionally deleted to avoid the logic research that tobacco contains addictive substances that are harmful to health. Until now, no one known who committed this illegal act. A lot of speculations emerged, one of which private actors allegedly influenced Parliament to remove the article. ${ }^{11}$

\section{Government Regulation No.109 Year 2012}

This law was implemented the article 116 of Law No. 36 Year 2009 about Health. Based on article 113 paragraph (2) Law No. 36 year 2009, tobacco products declared to be addictive substances. Addictive substances here defines as substances that cause addiction or dependence which endangers health, marked by behavioral and cognitive changes and physiological phenomena, a strong desire to consume the substance, difficulty in controlling its use, prioritizing the use of the substance over other activities, increased tolerance, and that can cause withdrawal symptoms. ${ }^{12}$

In general, the substance of Government Regulation No.109 Year 2012 consists of tobacco products (article 4-7), responsibilities of the central and local governments (article 8-52), community participation (article 53-56), and guidance and oversight (article 57-60). Some articles stipulate in this law are unclear. For example in article 10 paragraph (1) stated that any person who produces tobacco product in the form of smokeables are required to conduct level test of nicotine and tar content per stick for each variety produced. This article doesn't explain about limitation of nicotine or tar content. This unclear limitation will leads uncontrol content of cigarretes.

\section{Minister of Health Regulation No. 28 Year 2013}

This regulation is intended to provide guidelines for Tobacco Product industrialists to implement the imprinting of Health Warnings and Health Information on Tobacco Product Packaging. Since its enactment, there was missing health information, which must be imprinted on every item of Tobacco Product Packaging (article 10 paragraph (2) (c)). Beside information on production code, date, month, and year of production, information about expired date and customer service of the tobacco product also must be included in the packaging. Information about the expired date is also part of the obligation under the Law No. 8 Year 1999 about consumer protection.

${ }^{11}$ Abrory, Permainan State Private Sector dalam Hilangnya Pasal Tembakau di UU Kesehatan, available at http://abroryparadigmapengembara.blogspot.com/2011/10/permainan-state-private-sector-dalam 04.html. Last visited $21^{\text {st }}$ March 2014.

${ }^{12}$ Article 1 paragraph 1 Government Regulation No.109 Year 2012. 


\section{Joint Regulation between the Minister of Health No. 188/MENKES/PB/I/2011 and the Minister of Home Affairs No. 7 Year 2011}

This regulation is aimed to provide a reference standard for local governments in determining Non Smoking Areas in order to improve clean and health environment. ${ }^{13}$ Studies have shown that the beneficial effects of a smoke-free environment extend to the health of the patrons as well. ${ }^{14}$ For example in New York, after passed the similar smoking ban regulation, the air quality in the workplace has dramatically improved. ${ }^{15}$

Scope of Non Smoking Areas under this regulation consists of health care facilities, educational facilities, children's play areas, places of worship, public transportations, work places, public places, and other specified places. ${ }^{16}$ Work places and public places can provide special area for smoking with certain requirements: represent an open space or a space with a direct connection with the outside air such that air can circulate properly, be separate from the main building/site/rooms and other spaces used for activities, be away from the entrance and exit, and be away from where people come and go. ${ }^{17}$

This law will effective to enforce since local government adopt it to their local regulation (peraturan daerah) ${ }^{18}$ even in provincial and regency/city level. Enactment and enforcement of this law depend on the political will of the local government. For example in Yogyakarta's Special Province (Provinsi Daerah Istimewa Yogyakarta) practice, the legislative process on the enactment of Non Smoking Area local regulation start in 2012 but until now there is no clear status when this law being enacted. ${ }^{19}$

\footnotetext{
${ }^{13}$ Article 2 of Joint Regulation between the Minister of Health No. 188/MENKES/PB/I/2011 and the Minister of Home Affairs No. 7 Year 2011 (Hereinafter as 'Joint Regulation').

${ }^{14}$ Andrew Hyland, Mark Travers, \& James Repace, 7 City Air Monitoring Study (7Cam), March-April 2004, available at http:/ /www.tobaccofreekids.org/pressoffice/7camreport.pdf (last visited 21 ${ }^{\text {st }}$ March 2014). See Keith Woodeshick, “Smoking Ban Legislation in New Jersey: Should Casinos Be Immune From Smoke?”, 3 Rutgers J. L. \& Urb. Pol'y 496 (2006).

${ }^{15}$ Ibid. See also Smoking Ban Improves a City Health, available at http://www.nytimes.com/2009/01/13/health/ research/13prev.html?_r=0 (last visited $21^{\text {st }}$ March 2014).

${ }^{16}$ Joint Regulation, article 3 paragraph (1).

${ }^{17} \mathrm{Ibid}$, article 5.

${ }^{18}$ Ibid, article 6 paragraph (1).

${ }^{19}$ See Aktivis Desak Perda Kawasan Tanpa Rokok Disabkan, available at http://www.tempo.co/read/news/2013/ 01/09/058453210/Aktivis-Desak-Perda-Kawasan-tanpa-Rokok-Disahkan (last visited $4^{\text {th }}$ February 2014).
} 


\section{Advantages of the FCTC Ratification}

World Health Assembly (WHA) initiated the FCTC in May $1995 .{ }^{20}$ This treaty was adopted on $56^{\text {th }}$ of $\mathrm{WHA}^{21}$ and came into force on 27 February $2005 .{ }^{22}$ Currently, 178 states is legally binding to this treaty. ${ }^{23}$ There are currently 19 United Nations member states that are non-parties to the treaty include Indonesia. ${ }^{24}$ Indonesia is the only ASEAN member who doesn't ratify the FCTC.

\section{Table 1}

Ratification of the FCTC by the ASEAN Members

\begin{tabular}{|l|l|l|l|}
\hline ASEAN Members State & Signature Date & Ratification & Entry into Force \\
\hline Brunei Darussalam & $03 / 06 / 2004$ & $03 / 06 / 2004$ & $27 / 02 / 2005$ \\
Cambodia & $25 / 05 / 2004$ & $15 / 11 / 2005$ & $13 / 02 / 2006$ \\
Lao PDR & $29 / 06 / 2004$ & $06 / 09 / 2006$ & $05 / 12 / 2006$ \\
Malaysia & $23 / 09 / 2003$ & $16 / 09 / 2005$ & $15 / 12 / 2005$ \\
Myanmar & $2 / 10 / 2003$ & $21 / 04 / 2004$ & $27 / 02 / 2005$ \\
Philippines & $23 / 09 / 2003$ & $06 / 06 / 2005$ & $04 / 09 / 2005$ \\
Singapore & $29 / 12 / 2003$ & $14 / 05 / 2004$ & $27 / 02 / 2005$ \\
Thailand & $20 / 06 / 2003$ & $08 / 11 / 2004$ & $27 / 02 / 2005$ \\
Viet Nam & $03 / 09 / 2003$ & $17 / 12 / 2004$ & $17 / 03 / 2005$ \\
\hline
\end{tabular}

Source: $\mathrm{WHO}^{25}$

The FCTC was designed as a compromise solution between a purely recommendatory instrument and a binding convention, so as to engage countries in an "incremental and flexible normative exercise" in a novel area:26

"Member Nations first adopt a framework convention that calls for international cooperation in realizing broadly stated goals, and, ideally, parties to the convention will conclude separate protocols containing specific measures designed to implement those goals. Multilateral environmental organizations have used this model to foster international agreement on pollution control measures and to overcome the resistance of powerful commercial interests." ${ }^{27}$

${ }^{20}$ See Center for Tobacco Grower Research, The World Health Organization's Framework Convention on Tobacco Control, available at http:/ / tobaccogrowerresearch.com/fda/FDA_WHO.pdf (last visited 21 ${ }^{\text {st }}$ March 2014).

${ }^{21}$ FCTC was the first treaty adopted under article 19 of WHO Constitution. See Ruth Roemer, Allyn Taylor, and Jean Lariviere, "Origins of WHO Framework Convention on Tobacco Control”, Am J Public Health. 95(6): 936-938 (2005).

22 See Parties to the WHO Framework. Convention on Tobacco Control, http://www.who.int/fctc/signatories_parties/ en/index.html (last visited $4^{\text {th }}$ February 2014).

${ }^{23}$ Ibid.

${ }^{24}$ Indonesia is merely one of Asian states that are not ratifying the FCTC. See WHO Member States (by regions) that are NOT parties to the WHO Framework Convention on Tobacco Control, available at http://www.who.int/tobacco/ framework/non_parties/en/index.html (last visited $4^{\text {th }}$ February 2014).

${ }^{25}$ Parties to the WHO Framework Convention on Tobacco Control, loc.cit.

${ }^{26}$ Sam Foster Halabi, “The World Health Organization's Framework Convention on Tobacco Control: An Analysis of Guidelines Adopted by the Conference of the Parties”, 39 Ga. J. Int'l \& Comp. L. 121 (2010), p.124.

${ }^{27}$ The FCTC, Foreword. 
The main objective of the FCTC is "to protect present and future generations from the devastating health, social, environmental and economic consequences of tobacco consumption and exposure to tobacco smoke by providing a framework for tobacco control measures to be implemented by the state parties at the national, regional and international levels in order to reduce continually and substantially the prevalence of tobacco use and exposure to tobacco smoke" ${ }^{28}$

For Indonesia, ratification of the FCTC will give more advantages on tobacco control especially in harmonizing its national law with global standard on tobacco control, such as: a. strengthening national commitment to guarantee everyone enjoyment of the highest attainable standard of physical and mental health; b. imposing tax and other measures to reduce tobacco demand; c. giving limitation toward the contents and emissions of tobacco products; $d$. strenthening public awareness for the consequences of smoking; e. eliminating illicit trade of tobacco products; $\mathrm{f}$. restricting sales of tobacco products to minors; and g. harmonizing and cooperating work with other state member to reduce demand and supply tobacco products nationally and globally.

Guidelines for implementation has been prepared by Convention Secretariat in order to make state parties clear to meet their obligations under the provision of the Convention. Its content consist of: protection of public health policies with respect to tobacco control from commercial and other vested interests of the tobacco industry (article 5.3), protection from exposure to tobacco smoke (article 8), regulation of the contents of tobacco products and of tobacco product disclosures (article 9 and 10), packaging and labelling of tobacco products (article 11), education, communication, training, and pubkic awarness (article 12), tobacco advertising, promotion, and sponsorship (article 13), and demand reduction measures concerning tobacco dependence and cessation (article 14).

The FCTC is binding treaty for state parties. After ratification, state parties shall adopt key substance of the FCTC to their domestic law. In fact, the text of the FCTC is often vague and defers to domestic law, which makes enforceability at the domestic level even more challenging. ${ }^{29}$ This is in part because the FCTC establishes a broad frame - a set of minimum requirements - that state parties can develop and implement

\footnotetext{
${ }^{28}$ The FCTC, article 3.

${ }^{29}$ Oscar Cabrera and Alejandro Madrazo, "Human Rights as a Tool for Tobacco Control in Latin America", Salud Publica de Mexico 52: 288-97 (2010), p.288.
} 
in different ways, i.e. the FCTC gives a 'margin of appreciation' for state parties implementation. ${ }^{30}$ After ratification, Indonesia may implement minimum standard tobacco control under the FCTC by compromising with the national condition. This policy will guarantee the long process to reduce the harmful effects of tobacco products in Indonesia.

\section{Obstacles of the FCTC Ratification in Indonesia}

Until now, Indonesia is not yet the parties of the FCTC. Many issues appear on the ratification process of this treaty. In economic side, tobacco industries claimed that ratification would decrease national income from tax and investment. ${ }^{31}$ In political side, legislative and some of government agencies have never assertive to establish policy reduction of tobacco use. ${ }^{32}$ In human right side, certain groups of society declared that smoking is a part of constitutional right that should be protected. ${ }^{33}$ This study will analyse this main issues on the challenges of ratification by following explanation:

\section{Economic Issues}

The decline possibility of state income from tobacco industries becomes one of the central issues on the accession of the FCTC. In the economic side, state not only enjoy taxation income but also large-scale of employment, foreign direct investment, and tobacco agriculture. Following table describes the increasing domestic income year by year from the excise of tobacco: ${ }^{34}$

\footnotetext{
${ }^{30}$ Oscar A. Cabrera and Lawrence O. Gostin, "Human rights and the Framework Convention on Tobacco Control: mutually reinforcing systems", Int.J.L.C. 7(3), 285-303 (2011), p.291.

${ }^{31}$ Based on research did by International Center for Applied Finance and Economics (Intercafe) Institut Pertanian Bogor (IPB), stated that custom from cigarettes has increasing number every year. Ratification of FCTC will decrease state income from cigarettes. See Pengamat: Penerimaan negara Anjlok jika FCTC diratifikasi, available at http:// id.berita.yahoo.com/pengamat-penerimaan-negara-anjlok-jika-fctc-diratifikasi-134858377_finance.html (last visited 24 March 2014).

32 Andi Gunawan, Kebijakan Pemerintah Untuk Menghentikan Peredaran Rokok, available at http:// ayobangkitindonesiaku.wordpress.com/2008/03/04/kebijakan-pemerintah-untuk-menghentikan-peredaran-rokok/ (last visited 3 April 2014).

${ }^{33}$ Komunitas Kretek: Merokok. Adalah Hak Konstitusional, available at http:/ / demo.gatra.com/nusantara-1/ nasional1/20787-komunitas-kretek-merokok-adalah-hak-konstitusional.html (last visited 3 April 2014).

${ }^{34}$ Ministry of Finance Publication. See Fuad Hasan and Dwijono Hadi Darwanto, Prospek dan Tantangan Usahatani Tembakau Madura, SEPA Vol. 10 No.1: 63 - 70 (2013), p.63.
} 
Table 2

Realization Development Domestic Income from Tobacco Excise (In trilion IDR)

\begin{tabular}{|c|l|}
\hline Year & Income \\
\hline 2005 & 32.6 \\
2006 & 37.1 \\
2007 & 43.5 \\
2008 & 49.9 \\
2009 & 53.3 \\
2010 & 63.2 \\
2011 & 65.4 \\
\hline
\end{tabular}

Source: Indonesian Ministry of Finance

Excise tax of cigarretes in Indonesia is still lower than the other developing countries. Most of Indonesia's tobacco excise tax paid by consumers not more than $37 \%$ of its price..$^{35}$ This percentage is below from the national regulation ( $57 \%$ of the sales price) and global benchmark (70\% of the sales price). ${ }^{36}$ Low excise levels in the retail selling price, as well as large gaps within regions or between neighbouring countries, have a number of negative effects such as cross-border flows and increasing illicit trade, leading to loss of revenues and damage to public health policies. ${ }^{37}$

The FCTC uses price and tax measures as an effective and important means of reducing tobacco consumption. ${ }^{38}$ An unpublished study of aggregate data, however, reported that increases in tobacco excise rates in 2001 did not significantly reduce cigarette demand. ${ }^{39}$ These two conditions can be used by the Government to increase the tobacco tax at least based on the national regulation to achive highest state income. State also pays greater costs for cigarettes compared with revenues it receives from the tobacco industry. Research from the World Bank has shown that smoking is an absolute loss for almost the entire country. ${ }^{40}$ Income received by the state from the tobacco industry (taxes and so on) may be a large amount, but the direct and indirect losses caused by tobacco consumption are much greater. High costs must be incurred

\footnotetext{
${ }^{35}$ Ayda Yurekli, Presentation to meetings on tobacco economics, Bloomberg Foundation, New York, November 2007 in Sarah Barber, et.al., Ekonomi Tembakau di Indonesia, International Union Against Tuberculosis and Lung Disease (The Union), France, 2008, p.vi.

${ }^{36}$ Ibid.

${ }^{37}$ Report of the Working Group, Draft guidelines for the implementation of Article 6 of the WHO Framework Convention on Tobacco Control, FCTC/COP/5/8, 24 July 2012.

${ }^{38}$ The FCTC, art.6 (1).

${ }^{39}$ A. Achadi, W. Soerojo and S. Barber, "The relevance and prospects of advancing tobacco control in Indonesia", Health Policy 72(3) (2005), p.333-349.

${ }^{40}$ See Assesment of the Economic Costs of Smoking, World Health Organization Economics of Tobacco Toolkit, 2011, p.11-14.
} 
to pay for the healing of diseases caused by smoking, absence from work, loss of productivity and income, premature death, and also make people become poor because they spend longer the money to buy cigarettes. Furthermore, implementing tax policies will generate additional revenues to 6.5 billion $\mathrm{USD}^{41}$ that cover health care costs for tobacco-related illnesses between 484 million USD to 1.2 billion USD. ${ }^{42}$

Even if the increase tax intervene the worse demand of tobacco, based on particular simulation did by Sarah Barber, et.al. show that:

"... the increase of tobacco tax rates to double positive impact on the economy. The simulation further find that there are 60 sectors of the economy will get benefit if households minimize their expenditures for tobacco products. This expenditures can be diverted households to consume other goods or for investment. Economic output and household income will also increase, amounting to Rp 335.4 billion and $\operatorname{Rp} 491.6$ billion.

Similar simulation also found that increase in cigarette excise up to two times will result in increased employment as much as 281.135 people. This is because agriculture and tobacco industry ranks high in the economy, employment and wages." 43

\section{Political Challenges}

Both Indonesian excecutive government and legislative body have different efforts in the FCTC ratification. The government, which leads by Ministry of Health ${ }^{44}$, asked legislative board to support their ratification's initiative to preserve public health. ${ }^{45}$ However, most of the members of House of Representative have never assertive to reduce the tobacco use. They use the ordinary reason that the ratification of the FCTC will shut off the domestic cigarette's industry and harm to tobacco farmers. In fact, this reason was unproven if we learn from the other state practices. Based on data from the world's food agency (FAO) of tobacco production in countries that have ratified the FCTC does not decline. ${ }^{46}$ It is also supported by particular research

${ }^{41}$ Tobacco Cases in Indonesia, available at http://global.tobaccofreekids.org/files/pdfs/en/ Indonesia_tobacco_taxes_summary_en.pdf (last visited 3 April 2014), p.3.

${ }^{42}$ Ibid, p.1.

${ }^{43}$ Ibid, p.3.

${ }^{44}$ Four Indonesian ministries (Ministry of Manpower and Transmigration, Ministry of Trade, Ministry of Industry, and Ministry of State Secretary) were refusing government plan, which recommended by the Ministry of Health. See Ratifikasi Konvensi Rokok Dihadang Empat Menteri, available at http:/ /kemenperin.go.id/artikel/7686/RatifikasiKonvensi-Rokok-Dihadang-Empat-Menteri (last visited 8 April 2014).

${ }^{45}$ Based on the Indonesian 1945's Constitution stated that in concluding international treaties with other countries and also in treaty ratification, President shall get the House Representative's approval first.

${ }^{46}$ See "Economically sustainable alternatives to tobacco growing (in relation to Articles 17 and 18 of the WHO Framework Convention on Tobacco Control)", report of the working group, Conference of the Parties to the WHO Framework Convention on Tobacco Control, Seoul, Republic of Korea, 12-17 November 2012. 
that if farmer want to plant other than tobacco, they will get more economic benefits. ${ }^{47}$ Alternative crops that provide equal or greater benefit other than tobacco is the red onions, red chili peppers, and melons for the lowland as well as potatoes and red chili peppers to the highland. ${ }^{48}$

Recent effort done by the House of Representative is to legislate their initiative Draft of Tobacco's Law. This draft was becoming part of 2014's National Legislation Program (Program Legislasi Nasional). ${ }^{49}$ Legislative board claimed that this draft as the substitution of the FCTC ratification's effort done by the Government. ${ }^{50}$ Various NGO deny the Legislative effort because based on their argumentation this Draft will not effective and sides with tobacco industry. ${ }^{51}$

\section{Human Rights Controversy}

The word 'may' in the explanation of Article 115 in the Law No. 36 of 2009 deleted by the Constitutional Court based on its Decision No. 57/PUU/IX/2011 because of smoking is part of human right. This decision leads controversy in public's sphere. Right to smoke is not a basic human right. Therefore, the smoking ban will not make a person lose dignity as a human being. Without smoking even human health are well preserved.

Actually, tobacco control policy does not intended to cut the right to smoke, but the fight for the right of each person to breathe healthy air is the priority. ${ }^{52}$ It is

\footnotetext{
${ }^{47}$ Muchjidin Rachmat dan Sri Nuryanti, "Dinamika Agribisnis Tembakau Dunia dan Implikasinya Bagi Indonesia”, Forum Penelitian Agro Ekonomi Vol.7 (2): 73- 91 Pusat Analis Sosial Ekonomi dan Kebijakan Pertanian, Departemen Pertanian (2009), p.91.

${ }^{48}$ Technical Assistance for Developing "Booklet of Tobacco Economics in Indonesia, Demographic Institute Faculty of Economics University of Indonesia (2010), available at http://whoindonesia.healthrepository.org/bitstream/ 123456789/643/1/Booklet $\% 20$ of $\% 20$ Tobacco\%20Economics...\%28INO\%20FFC\%20011\%20XK\%2008\%20SE-09228726\%29.pdf (last visited 11 April 2014).

49 Based on the National Legislation Program, Draft of Tobacco's Act (Rancangan Undang-Undang Pertembakauan) becomes one of the list (No. 51) that will be discussed and enacted in 2014. See Program Legislasi Nasional Rancangan Undang-Undang Prioritas Tahun 2014, available at http://www.dpr.go.id/complorgans/baleg/ prolegnas_PROGRA M_LEGISLASI_NASIONAL__RA N C A N G N_U N D N G UNDANG_PRIORITAS_TAHUN_2014.pdf (last visited 8 April 2014).

${ }^{50}$ Legislator: ratifikasi FCTC tumpang tindih RUU pertembakauan, available at http:/ / www.antaranews.com/suaraparlemen/berita/422175/legislator-ratifikasi-fctc-tumpang-tindih-ruu-pertembakauan (last visited 8 April 2014).

${ }^{51}$ NGO such as YLKI (Indonesian Consumers Organization) and National Commission on Human Rights argue that substance on Draft of Tobacco's Act was the result of tobacco industry lobbys and addictive measure of tobacco as stated in the Health Act give the Government authorization to control and evaluate the existance of tobacco. See RUU Tembakau: Berpihak Kepada Petani atau Industri Rokok?, available at http://www.ylki.or.id/ruu-tembakauberpihak-kepada-petani-atau-industri-rokok.html (last visited on 8 April 2014). Komnas HAM Minta RUU Tembakau Tak.Masuk Prolegnas 2014, available at http://m.hukumonline.com/berita/baca/lt52aac70da0db4/komnas-ham-mintaruu-tembakau-tak-masuk-prolegnas-2014 (last visited on 8 April 2014).

${ }^{52}$ Mardiyah Chamim, et.al., A Giant Pack of Lies Bongkah Raksasa Kebohongan: Menyorot Kedigdayaan Industri Rokok di Indonesia, Jakarta: Tempo Institute, 2011, p.171-174.
} 
because the right of health actually becomes non-derogable right ${ }^{53}$ that should have prior respect. Indonesian government can use the protection of public health as basic consideration to ratify the FCTC.

\section{Examples of Effective Ratification}

As a state that is present within the international community, Indonesia has an obligation to respect and implement international agreements that has been ratified. Practically after ratification, Indonesia will compromise and harmonise its existing law to the international obligations. This adoption process usually resulted effective implementation to solve certain national problems. This paper gives some effective implementation of international treaty ratification in Indonesia, such as: First, Indonesia ratified Convention on the Elimination of All Forms of Discrimination Against Women ${ }^{54}$ by the Law No. 7 Year 1984. By this ratification, Indonesia ensure through legislation, policies, programs and temporary special measures to realize equality and equity between men and women. The effectiveness of this ratification marked by numerous laws which are removed and replaced with legislation that is pro-gender equality, i.e. Law No. 8 Year 2012 about General Elction which guarantee 30\% quotas for women to sit down in parliement and the enaction of Law No. 23 Year 2004 about Elimination of Domestic Violence gives more protection for women who usually being targetted victim of violence. Second, Ratification of ILO Convention No. 138 Concerning Minimum Age for Admission to Employment ${ }^{55}$ through Law No. 20 of 1999 and the ratification of ILO Convention No. 182 Concerning the Prohibition and Immediate Action for the Elimination of the Worst Forms of Child Labour ${ }^{56}$ through Law No. 1 of 2000 provides a framework for the protection of legal certainty children's rights in Indonesia. Indonesia guarantees to protect the right of children by setting the Law No. 23 of 2004 on the Protection of Children. These regulation directly impact on governmental policies related to the fulfillment of children's rights, prohibition of children to work and being victim of human trafficking, and the establishment of a National Committee of Children's Protection (Komisi Nasional Perlindungan Anak) as

\footnotetext{
${ }^{53}$ N. Swazo, "The Right to Health, International Law, and Economic Justice", The Internet Journal of Law, Healthcare and Ethics, Volume 5 Number 1 (2006), available at http:/ /ispub.com/IJLHE/5/1/10223\# (last visited on 8 April 2014).

${ }^{54}$ Convention on the Elimination of all Forms of Discrimination Against Women, Dec. 18, 1979, 1249 U.N.T.S. 13.

${ }^{55}$ International Labour Organization (ILO), Minimum Age Convention, C138, June 26, 1973, 1015 U.N.T.S. 297.

${ }^{56}$ International Labour Organization (ILO), Worst Forms of Child Labour Convention, C182, June 17, 1999, 2133 U.N.T.S. 161.
} 
formal task force that directly address the problems of children in Indonesia. Third, To prevent crime and abuse of narcotics and illegal drugs, Indonesia ratified the Single Convention on Narcotic Drugs $(1961)^{57}$ and its Protocol amending the Single Convention on Narcotic Drugs (1972) ${ }^{58}$ through Law No. 8 of 1976. In addition, Indonesia has also ratified the United Nations Convention Against Illicit Traffic in Narcotic Drugs and Psychotropic Substances through Law No. 7 of 1997. To meet these international obligations, specifically Indonesia then arrange Law No. 35 of 2009 on Narcotics and Law No. 5 of 1997 about Pshychotropic. This regulation provides the categorization of narcotics drugs into three groups ranging from the considered dangerous to the least dangerous. Effectively, the Government established the National Narcotics Agency (Badan Narkotika Nasional) as special task force to handle the cases of crime and drug abuse that are increasingly sophisticated.

\section{Conclusion}

After all, in terms of health, cigarette is very harmful for both active smoking and passive smoking. As the realization of the right to run the health standards for every citizen, the state has authority to restrict tobacco use because of its addictive. Tobacco control in Indonesia is still not showing significant results to address health issues. Indonesian policy on tobacco control always face with obstacles in the area of politic, economic, and human rights side. This is in line with the lack integrated and systematic regulations related to the tobacco control in Indonesia. Most of the laws are still abstract to support public health in general.

Ratification of the FCTC will be the only solution for Indonesia to harmonize its domestic policy to the international obligations under the FCTC. The FCTC requires state parties to impose restrictions on tobacco advertising, sponsorship and promotion, and to establish new packaging and labeling for tobacco products. Moreover, specific researches prove and support that ratification efforts to the FCTC would not decrease state financial income, give full legal certainty, and even more protect public right to health. Furthermore, based on previous Indonesian practices show that ratification of particular international treaties effectively solve certain cases by progressive way. Thus, there is no need to worry for Indonesia to face obstacle's possibilities since tobacco is always endangers human health.

\footnotetext{
${ }^{57}$ Single Convention on Narcotic Drugs, 1961, 520 U.N.T.S. 204.

${ }^{58}$ Protocol Amending the Single Convention on Narcotic Drugs, 1972, 976 U.N.T.S. 3.
} 


\section{Refferences}

Barber, Sarah, et.al., Ekonomi Tembakau di Indonesia, International Union Against Tuberculosis and Lung Disease (The Union), France, 2008.

Chamim, Mardiyah, et.al., A Giant Pack of Lies Bongkah Raksasa Kebohongan: Menyorot Kedigdayaan Industri Rokok di Indonesia, Jakarta: Tempo Institute, 2011.

Achadi, A., Soerojo, W. and Barber, S. "The relevance and prospects of advancing tobacco control in Indonesia", Health Policy 72(3) (2005).

Cabrera, Oscar and Gostin, Lawrence, "Human rights and the Framework Convention on Tobacco Control: mutually reinforcing systems", Int. J.L.C. 7(3), 285-303 (2011).

Cabrera, Oscar and Madrazo, Alejandro, "Human Rights as a Tool for Tobacco Control in Latin America", Salud Publica de Mexico 52: 288-97 (2010).

Darmawansyah, “Upaya Kesehatan di Indonesia: Tantangan dan Harapan”, Jurnal Administrasi dan Kebijakan Kesehatan Indonesia, Vol 2 No.2, May 2013.

Halabi, Sam Foster, “The World Health Organization's Framework Convention on Tobacco Control: An Analysis of Guidelines Adopted by the Conference of the Parties", 39 Ga. J. Int'l E Comp. L. 121 (2010).

Hasan, Fuad and Darwanto, Dwijono Hadi, Prospek dan Tantangan Usahatani Tembakau Madura, SEPA Vol. 10 No.1: 63 - 70 (2013).

M. Flood, Colleen and Trudo Lemmens, "Global Health Challenges and The Role of Law", J.L. Med. E Ethics, Vol.41 (2013).

Rachmat, Muchjidin dan Nuryanti, Sri, “Dinamika Agribisnis Tembakau Dunia dan Implikasinya Bagi Indonesia", Forum Penelitian Agro Ekonomi Vol.7 (2): $73-$ 91 Pusat Analis Sosial Ekonomi dan Kebijakan Pertanian, Departemen Pertanian (2009).

Roemer, Ruth, Taylor, Allyn, and Lariviere, Jean, “Origins of WHO Framework Convention on Tobacco Control", Am J Public Health. 95(6): 936-938 (2005).

Soerojo, Widyastuti, “Epidemi Tembakau di Indonesia Tantangan Bagi Petugas Kesehatan", paper on the Workshop Peningkatan Kapasitas Sektor Kesehatan Dalam Pengendalian Masalah Tembakau, Direktorat Pengendalian Penyakit Tidak Menular, Departemen Kesehatan Republik Indonesia, September 2007.

Woodeshick, Keith, "Smoking Ban Legislation in New Jersey: Should Casinos Be Immune From Smoke?", 3 Rutgers J. L. E Urb. Pol'y 496 (2006).

Indonesian 1945's Constitution.

Law No. 36 Year 2009 about Health.

Government Regulation No. 109 Year 2012 about Securing Material Containing Addictive Substances.

Minister of Health Regulation No. 28 Year 2013 about Imprinting of Health Warnings and Health Informations on Tobacco Product Packaging. 
Joint Regulation between the Minister of Health No. 188/MENKES/PB/I/2011 and the Minister of Home Affairs No. 7 Year 2011 about Guideline Implementation of Non Smoking Area.

UN Declaration of Human Rights (1948).

Single Convention on Narcotic Drugs, 1961, 520 U.N.T.S. 204.

International Covenant for Economic Social and Cultural Rights (1966).

Protocol Amending the Single Convention on Narcotic Drugs, 1972, 976 U.N.T.S.3.

International Labour Organization (ILO), Minimum Age Convention, C138, June 26, 1973, 1015 U.N.T.S. 297.

Convention on the Elimination of all Forms of Discrimination Against Women, Dec. 18, 1979, 1249 U.N.T.S. 13.

International Labour Organization (ILO), Worst Forms of Child Labour Convention, C182, June 17, 1999, 2133 U.N.T.S. 161.

WHO Framework Convention on Tobacco Control, May 21, 2003-June 29, 2004, WHA56.1, 2302 U.N.T.S. 166, 42 I.L.M. 518.

Abrory, Permainan State Private Sector dalam Hilangnya Pasal Tembakau di UU Kesehatan, available at http:/ / abrory-paradigmapengembara.blogspot.com/2011/10/ permainan-state-private-sector-dalam_04.html (last visited $21^{\text {st }}$ March 2014).

Aktivis Desak Perda Kawasan Tanpa Rokok Disahkan, available at http:/ / www.tempo.co/ $\mathrm{read} /$ news/2013/01/09/058453210/Aktivis-Desak-Perda-Kawasan-tanpaRokok-Disahkan (last visited $4^{\text {th }}$ February 2014).

Assesment of the Economic Costs of Smoking, World Health Organization Economics of Tobacco Toolkit, 2011.

Ayat Tembakau Hilang di DPR, available at http:/ / nasional.kompas.com/read/2009/ 10/14/04594644/ayat.tembakau.hilang.di.dpr (last visited 21 ${ }^{\text {st }}$ March 2014).

Badan Pusat Statistik (BPS/National Statistic Council), Survei Sosial Ekonomi Nasional (The National Socioeconomic Survey), Jakarta, 2006.

Center for Tobacco Grower Research, The World Health Organization's Framework Convention on Tobacco Control, available at http:/ / tobaccogrowerresearch.com/ fda/FDA_WHO.pdf (last visited 21 ${ }^{\text {st }}$ March 2014).

"Economically sustainable alternatives to tobacco growing (in relation to Articles 17 and 18 of the WHO Framework Convention on Tobacco Control)", report of the working group, Conference of the Parties to the WHO Framework Convention on Tobacco Control, Seoul, Republic of Korea, 12-17 November 2012.

Gunawan, Andi, Kebijakan Pemerintah Untuk Menghentikan Peredaran Rokok, available at http:/ / ayobangkitindonesiaku.wordpress.com/2008/03/04/kebijakanpemerintah-untuk-menghentikan-peredaran-rokok/ (last visited 3 April 2014).

Hyland, Andrew, Travers, Mark, \& Repace, James, 7 City Air Monitoring Study (7Cam), March-April 2004, available at http:/ / www.tobaccofreekids.org/pressoffice/ 7camreport.pdf (last visited 21 ${ }^{\text {st }}$ March 2014). 
Indonesia Masuk Tiga Besar Konsumen Rokok, available at http:/ / www.arrahmah.com/ $\mathrm{read} / 2012 / 12 / 01 / 25181$-indonesia-masuk-tiga-besar-konsumen-rokok.html (last visited 9 April 2014).

Indonesia Struggling to Deter Children from Smoking, available at http:// english.peopledaily.com.cn/90001/90782/90880/7122690.html (last visited 9 April 2014).

Joni, Muhammad, Pasal Tembakau Terbanyak Uji Materiil: (Itu) Kontrol Bukan Diskriminasi, available at http://www.advokatmuhammadjoni.com/opini/tulisan/170pasal-tembakau-terbanyak-uji-materil-itu-kontrol-bukan-diskriminasi.html (last visited $21^{\text {st }}$ March 2014).

Komnas HAM Minta RUU Tembakau Tak Masuk Prolegnas 2014, available at http:// m.hukumonline.com/berita/baca/lt52aac70da0db4/komnas-ham-mintaruu-tembakau-tak-masuk-prolegnas-2014 (last visited on 8 April 2014).

Komunitas Kretek: Merokok Adalah Hak Konstitusional, available at http:// demo.gatra.com/nusantara-1/nasional-1/20787-komunitas-kretekmerokok-adalah-hak-konstitusional.html (last visited 3 April 2014).

Legislator: ratifikasi FCTC tumpang tindih RUU pertembakauan, available at http:/ / www.antaranews.com/suara-parlemen/berita/422175/legislator-ratifikasifctc-tumpang-tindih-ruu-pertembakauan (last visited 8 April 2014).

Parties to the WHO Framework Convention on Tobacco Control, http:/ / www.who.int/ fctc/signatories_parties/en/index.html (last visited $4^{\text {th }}$ February 2014).

Pengamat: Penerimaan negara Anjlok jika FCTC diratifikasi, available at http:/ / id.berita.yahoo.com/pengamat-penerimaan-negara-anjlok-jika-fctcdiratifikasi-134858377-finance.html (last visited 24 March 2014).

Program Legislasi Nasional Rancangan Undang-Undang Prioritas Tahun 2014, available at h t t p : / / w w w.d p r.go.id / c o m p lo r g a n s / b a l e g / prolegnas_PROGRAM_LEGISLASI_NASIONAL_RANCANGAN_UNDANGUNDANG_PRIORITAS_TAHUN_2014.pdf (last visited 8 April 2014).

Ratifikasi Konvensi Rokok Dihadang Empat Menteri, available at http:/ / kemenperin.go.id/ artikel/7686/Ratifikasi-Konvensi-Rokok-Dihadang-Empat-Menteri (last visited 8 April 2014).

Report of the Working Group, Draft guidelines for the implementation of Article 6 of the WHO Framework Convention on Tobacco Control, FCTC/COP/5/8, 24 July 2012.

RUU Tembakau: Berpihak Kepada Petani atau Industri Rokok?, available at http:/ / www.ylki.or.id/ruu-tembakau-berpihak-kepada-petani-atau-industrirokok.html (last visited on 8 April 2014).

Smoking Ban Improves a City Health, available at http:/ / www.nytimes.com/2009/01/ 13/health/research/13prev.html?_r=0 (last visited $21^{\text {st }}$ March 2014).

Swazo, N., "The Right to Health, International Law, and Economic Justice”, The Internet Journal of Law, Healthcare and Ethics, Volume 5 Number 1 (2006), available at http:/ /ispub.com/IJLHE/5/1/10223\# (last visited on 8 April 2014). 
Technical Assistance for Developing "Booklet of Tobacco Economics in Indonesia, Demographic Institute Faculty of Economics University of Indonesia (2010), available at http:/ /whoindonesia.healthrepository.org/bitstream/123456789/643/1/ Booklet $\%$ 20of \% 20Tobacco \% 20Economics... \% 28INO \%20FFC \% 20011\% 20XK\%2008\%20SE-09-228726\%29.pdf (last visited 11 April 2014).

Tobacco Cases in Indonesia, available at http:/ / global.tobaccofreekids.org/files/pdfs / en/Indonesia_tobacco_taxes_summary_en.pdf (last visited 3 April 2014).

WHO Member States (by regions) that are NOT parties to the WHO Framework Convention on Tobacco Control, available at http://www.who.int/tobacco/framework/ non_parties/en/index.html (last visited $4^{\text {th }}$ February 2014). 